\title{
Feeding of lantern fish Benthosema glaciale off the Nova Scotia Shelf
}

\author{
D. D. Sameoto \\ Department of Fisheries and Oceans, Biological Sciences Branch, Bedford Institute of Oceanography, PO Box 1006, Dartmouth, \\ Nova Scotia, Canada B2Y 4A2
}

\begin{abstract}
Benthosema glaciale populations on the slope of the Nova Scotia shelf were sampled at different months of the year on 8 occasions over 8 yr. Day/night vertical distributions are described in relation to distributions of their zooplankton prey. Feeding behavior was studied from stomach contents which showed feeding primarily on copepods during the night in the upper $200 \mathrm{~m}$, but some daytime feeding at depths greater than $300 \mathrm{~m}$. A modified Ivlev's electivity index showed B. glaciale positively selected certain species of copepods but not the most abundant Calanus finmarchicus, although this species was the most common species in its diet. B. glaciale tended to select copepod species whose body length was greater than $1 \mathrm{~mm}$. Size range of prey increased with fish body length; however larger fish continued to feed on the same small prey as smaller fish. The estimated daily ration of B. glaciale decreased with body weight and ranged from $8 \%$ of body weight for a $0.1 \mathrm{~g}$ fish to $2.5 \%$ for a $3 \mathrm{~g}$ fish. The B. glaciale population was estimated to consume between 0.2 and $0.1 \%$ of the zooplankton biomass per day during spring but only $0.03 \%$ in fall
\end{abstract}

\section{INTRODUCTION}

The lantern fish Benthosema glaciale is the dominant mesopelagic fish in a zone between the $1000 \mathrm{~m}$ contour and the front of slope water of the Nova Scotian shelf (Sameoto 1982). This myctophid is known to migrate vertically each night to the upper $100 \mathrm{~m}$ of water to feed on zooplankton, its principle prey (Gjøsaeter \& Kawaguchi 1980), but little is known about its specific prey selection, the depth at which it feeds, or its daily ration. Nor is anything known about its feeding habits on the Nova Scotia slope during different seasons of the year. This study was designed to investigate the specific prey consumed by $B$. glaciale of various sizes, the depths and times at which feeding occurred, as well as changes in the feeding behaviour with different seasons of the year. In addition the daily ration in terms of fish body weight was estimated for different size classes of fish.

\section{METHODS}

Samples of zooplankton and mesopelagic fish were taken simultaneously with the BIONESS, a multiple net sampler with ten $1 \mathrm{~m}^{2}$ nets of mesh size $243 \mu \mathrm{m}$
(Sameoto et al. 1980). The BIONESS measured depth, volume of water filtered by each net, speed inrough the water, temperature and salinity. It was towed at a speed of 3 knots while being slowly lowered to the maximum sampling depth. Each of the nets was opened and closed at predetermined depths $110 \mathrm{~m}$ intervals in the top $100 \mathrm{~m}$ and ca $50 \mathrm{~m}$ intervals at all other depths) on an oblique path to a maximum depth of $1400 \mathrm{~m}$. Sampling was carried out on 8 occasions over 8 yr (April 1979, 1983; May 1977; June 1978; July 1982; October 1981, 1984, 1985). The location of the sampled stations and sample dates are shown in Fig. 1.

Fish and zooplankton samples were preserved in a $4 \%$ formalin and seawater solution buffered with sodium borate and strontium chloride. All myctophids were identified to species, and total length measured from the snout to the end of the caudal peduncle. All myctophids were weighed wet and the stomach dissected out by cutting it at the posterior end of the esophagus and at the pyloric valve. The stomach was weighed wet, then dissected under a microscope and the percent fullness in terms of volume estimated and assigned to one of the following categories: (1) empty; (2) $1 \%$ full (usually with only 1 or 2 particles); (3) $25 \%$ full; (4) $50 \%$; (5) $75 \%$ full (stomach had some space between food particles); (6) $100 \%$ full (stomach walls 

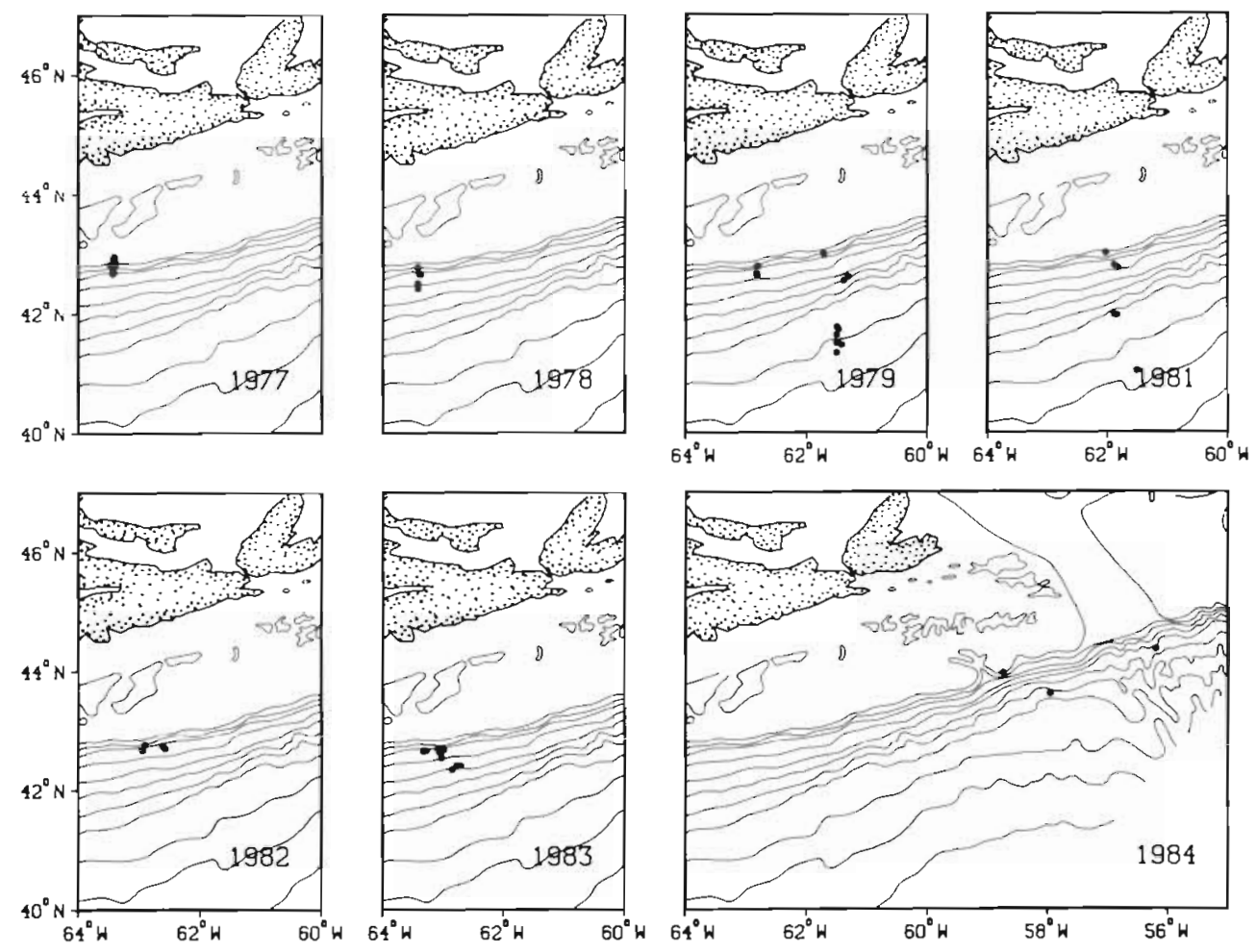

Fig. 1. Location of sampling stations on the Nova Scotia slope. Each dot represents a separate BIONESS station

were stretched with no space apparent between food particles).

The stomach contents were identified to lowest possible taxa, usually genera, and counted. The length and width of each particle were measured. The stomach lining was weighed wet and subtracted from the total weight of the stomach and contents to estimate the total weight wet of the contents.

The state of digestion of the stomach contents was estimated and assigned to one of the following categories; (1) complete digestion - all material unidentifiable; (2) partial digestion - whole copepods recognizable, with minimum to moderate digestion; (3) undigested - whole organisms in good condition. Fish of all lengths within each sample were examined for stomach contents.

The problem of postcapture ingestion ('net feeding') by fish is always a concern with in situ feeding studies, particularly with mesopelagic fish. Hopkins \& Baird (1975) reviewed net feeding and concluded it was not a serious problem for many midwater fish. Clarke (1978, 1980), Rohwedder (1980) and Imsand (1981) found little evidence of net feeding. Lancraft \& Robison (1980) found only $5 \%$ of the fish ingested artificial prey introduced into the cod end. The amount of artificial prey ingested varied with species and was highest in the large species that were recovered alive from the nets and very low in the small fragile species of fish. The incidence of cod end feeding was higher by day than night, and small particles were more readily consumed than large ones. Roe \& Badcock (1984) examined the problem of net feeding in the RMT 8 (an opening and closing midwater trawl) and concluded that for planktivorous fish, including Benthosema, it was not an important problem and the small degree of contamination due to the fish gulping in the net was probably undetectable.

Cod-end feeding during BIONESS sampling was not considered a serious problem for the following reasons. First, the fish when captured, even in short tows of 10 min or less, were usually dead or dying even though their physical appearance was still very good. Second, the speed of the tow meant that the fish were forced against the mesh of the net and it is unlikely that they would be inclined or able to feed under these circumstances. Third, the high numbers of fish with empty stomachs at all depths during both day and night indicate that cod end feeding was not a common occurrence. There was no evidence that fish regurgitation was a problem with captured fish at any time.

A quantitative measure of food selection was made for fish at different depths using a modified Ivlev's electivity index, $D_{i}$ (Jacobs 1974). This index was calculated as

$$
D_{i}=\frac{r-p}{r+p-2 r p}
$$

where $r=$ proportion of a prey species in the stomach: $p=$ proportion of that prey in the zooplankton sample. 
This index is different from Ivlev's (1961) in that it is independent of the relative abundance of the prey species. The value of $D_{1}$ varies from -1 to 0 for negative selection and 0 to +1 for positive selection.

\section{RESULTS}

\section{Physical oceanography}

During April and June the water column to a depth of $1000 \mathrm{~m}$ was a 3-layered system (Fig. 2). A cold (3 to $\left.4{ }^{\circ} \mathrm{C}\right)$, relatively less saline $(<35 \%$ ) layer of Shelf Water

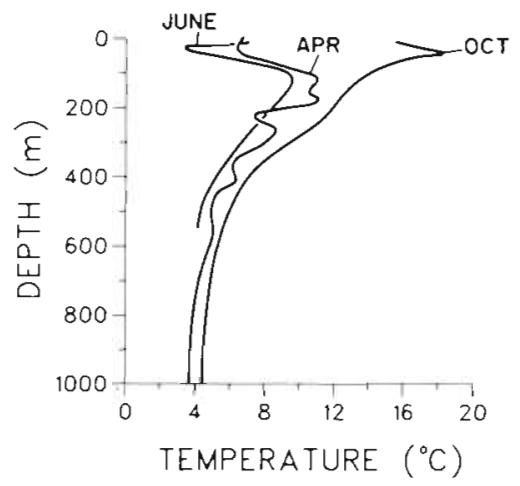

Fig. 2. Temperature profiles showing changes with months in the sampled area

extended from the surface to about $100 \mathrm{~m}$, Below this layer was the warmer and more saline Slope Water $\left(8{ }^{\circ} \mathrm{C} ;>35 \%\right.$ ) which reached a depth of about $350 \mathrm{~m}$. Below this was the colder Labrador Slope Water 4 to $5^{\circ} \mathrm{C} ;<35 \%$ )

In October the water column structure was quite different. A warm layer $\left(18^{\circ} \mathrm{C} ;>35 \%\right)$ of warm core water was found from the surface of a depth of about $400 \mathrm{~m}$ and below this layer was found North Atlantic Central Water $\left(5\right.$ to $6^{\circ} \mathrm{C}$ and $35 \%$ ) which extended to below $1000 \mathrm{~m}$. This pattern of water column structure is similar to that found by Fedulov \& Arkhipkin (1986) on the Nova Scotia slope.

\section{Seasonal abundance of myctophids}

Concentrations of myctophids found in June were significantly higher than in April or May. In October, concentrations of Benthosema glaciale were significantly lower than in spring (Table 1). B. glaciale was the dominant species of mesopelagic fish during all months sampled, though 12 other species of myctophids were found in low concentrations (Table 2).

The population of myctophids was significantly reduced relative to the biomass of total zooplankton during October (Table 1). During this time the temperature in the top $400 \mathrm{~m}$ (Fig. 2) was significantly higher than in the earlier part of the year. Myctophid biomass ranged between 3.7 and $8.4 \%$ of the zooplankton biomass $\mathrm{m}^{-2}$ in the top $500 \mathrm{~m}$ during April and June, but was only $0.4 \%$ of the total zooplankton biomass in the top $1000 \mathrm{~m}$ in October. A reduced myctophid population was seen during both the 1981 and 1984 October sampling periods. Sampling to a depth of $1400 \mathrm{~m}$ in October 1985 showed no myctophids below $800 \mathrm{~m}$.

\section{Length frequencies}

The length range of Benthosema glaciale (Table 3; Fig. 3) was greatest during April (15 to $80 \mathrm{~mm}$ ), and was lowest during June ( 30 to $60 \mathrm{~mm}$ ) with the largest mean length found in April. No significant difference was found in total lengths of specimens caught between day and night sampling during any of the months, nor were significant differences found between the lengths of specimens at different depths during the day or night. The size class structure was multi-modal for all months with small fish dominating the October population.

\section{Vertical distribution of myctophids and zooplankton}

The highest concentrations of copepods per m ${ }^{3}$ occurred during June and the lowest - an order of magnitude lower - during October (Table 1). The maximum concentrations of zooplankton per $\mathrm{m}^{3}$ for all months were found in the upper $100 \mathrm{~m}$ during the day and in the upper $30 \mathrm{~m}$ at night (Figs. $4 \mathrm{a}, \mathrm{b}$ and 5). Calanus, the dominant genus during all months, had its highest concentrations in the top $30 \mathrm{~m}$ from April to July. In October the maximum copepod concentration was at approximately $300 \mathrm{~m}$.

The main concentration of zooplankton in all months except October was generally found above the main concentration of myctophids at night. At a few stations the main concentration of myctophids was found at the same depth as the zooplankton maximum (Figs. 4 and 5). In April 1983 the concentrations of Clausocalanus spp., Eucalanus spp., Euchaeta spp., Euchirella spp., Pleuromamma spp. and Oithona spp. closely overlapped the distribution of Benthosema glaciale in the upper $200 \mathrm{~m}$ at night.

The majority of the Benthosema glaciale population during the day in April to July was found between 350 and $450 \mathrm{~m}$ with low concentrations as deep as $950 \mathrm{~m}$ and as shallow as $25 \mathrm{~m}$. The myctophid populations during these months always migrated vertically at 


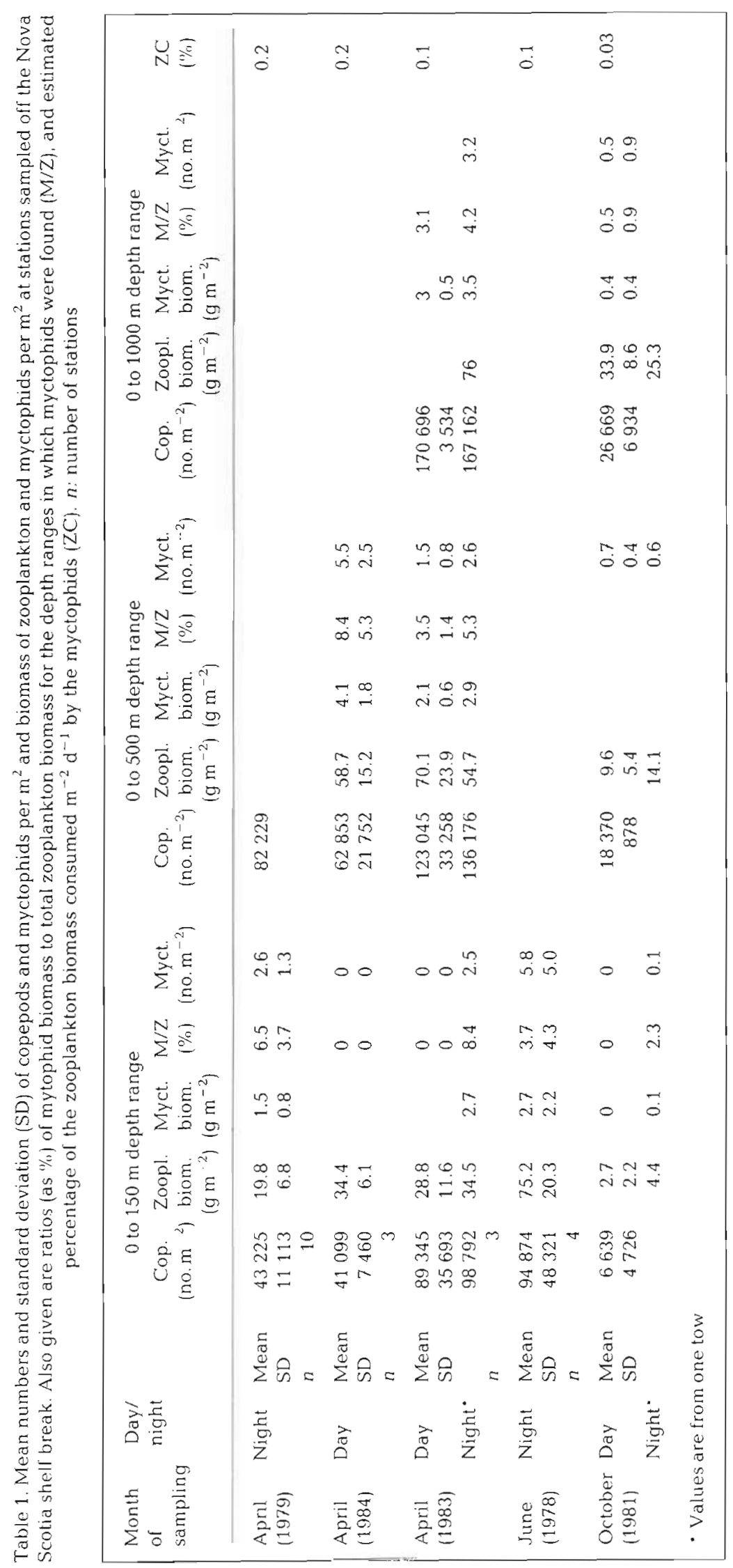


Table 2. Percentages of various species of myctophids and total number collected in different months and years

\begin{tabular}{|c|c|c|c|c|c|c|c|}
\hline Species & $\begin{array}{c}\text { April } \\
1979\end{array}$ & $\begin{array}{l}\text { April } \\
1983\end{array}$ & $\begin{array}{l}\text { May } \\
1977\end{array}$ & $\begin{array}{c}\text { June } \\
1978 \\
\%\end{array}$ & $\begin{array}{l}\text { July } \\
1982\end{array}$ & $\begin{array}{c}\text { October } \\
1981\end{array}$ & $\begin{array}{c}\text { October } \\
1984\end{array}$ \\
\hline Benthosema glaciale & 97.27 & 95.57 & 58.18 & 100 & 100 & 41.07 & 100 \\
\hline Ceratoscopelus maderensis & 0.21 & - & 7.27 & - & - & 25.00 & - \\
\hline Unidentified myctophid & 0.63 & - & 14.54 & - & - & 14.28 & - \\
\hline Lampanyctus sp. & - & - & 7.27 & - & - & 3.57 & - \\
\hline Diogenichthys atlanticus & 0.42 & - & 3.64 & - & - & 1.78 & - \\
\hline Lobianchiasp. & - & - & - & - & - & 7.14 & - \\
\hline Diaphus sp. & 0.63 & 1.77 & - & - & - & 1.78 & - \\
\hline Benthosema suborbitale & - & - & 5.45 & - & - & - & - \\
\hline Hygophum sp. & 0.42 & - & - & - & - & 1.78 & - \\
\hline Bolinchthys sp. & - & - & 3.64 & - & - & 1.78 & - \\
\hline Notolynchus sp. & 0.21 & - & - & - & - & 1.78 & - \\
\hline Symbolophorus sp. & 0.21 & 0.88 & - & - & - & - & - \\
\hline Lepidophanessp. & - & 1.77 & - & & - & - & - \\
\hline Total number & 477 & 113 & 55 & 401 & 37 & 56 & 50 \\
\hline
\end{tabular}

Table 3. Benthosema glaciale. Sample size measured for the various months and years plus the mean and standard deviation (SD) of the body lengths, mode, minimum and maximum body length and mean wet weight

\begin{tabular}{|c|c|c|c|c|c|c|c|}
\hline \multirow[t]{2}{*}{ Month } & \multirow[t]{2}{*}{ Year } & \multirow[t]{2}{*}{ No. } & \multicolumn{4}{|c|}{ Body length (mm) } & \multirow{2}{*}{$\begin{array}{c}\text { Mean wt } \\
\text { (g) }\end{array}$} \\
\hline & & & $\begin{array}{c}\text { Mean } \pm \text { SD } \\
(\mathrm{mm})\end{array}$ & $\begin{array}{l}\text { Mode } \\
(\mathrm{mm})\end{array}$ & $\begin{array}{l}\mathrm{Min} \\
(\mathrm{mm})\end{array}$ & $\begin{array}{l}\text { Max. } \\
(\mathrm{mm})\end{array}$ & \\
\hline April & 1979 & 451 & $34.7 \pm 9.3$ & 28 & 13 & 68 & 0.44 \\
\hline April & 1984 & 47 & $42.8 \pm 6.7$ & 45 & 27 & 60 & 0.84 \\
\hline April & 1983 & 99 & $44.5 \pm 11.7$ & 44 & 15 & 76 & 0.96 \\
\hline May & 1977 & 33 & $40.1 \pm 19.5$ & 30 & 11 & 83 & 0.66 \\
\hline June & 1978 & 401 & $36 \pm 5.1$ & 35 & 28 & 65 & 0.49 \\
\hline July & 1982 & 37 & $41.7 \pm 9.6$ & 37 & 27 & 61 & 0.77 \\
\hline October & 1981 & 21 & $28.5 \pm 14$ & 19 & 15 & 62 & 0.27 \\
\hline October & 1984 & 50 & $38.9 \pm 16.1$ & 21 & 17 & 68 & 0.61 \\
\hline
\end{tabular}

Fig. 3. Benthosema glaciale. Length frequencies, mean length $(\bar{X}) \pm$ standard deviation $(\mathrm{SD})$ and number of fish measured $(\mathrm{N})$ for different sampling periods

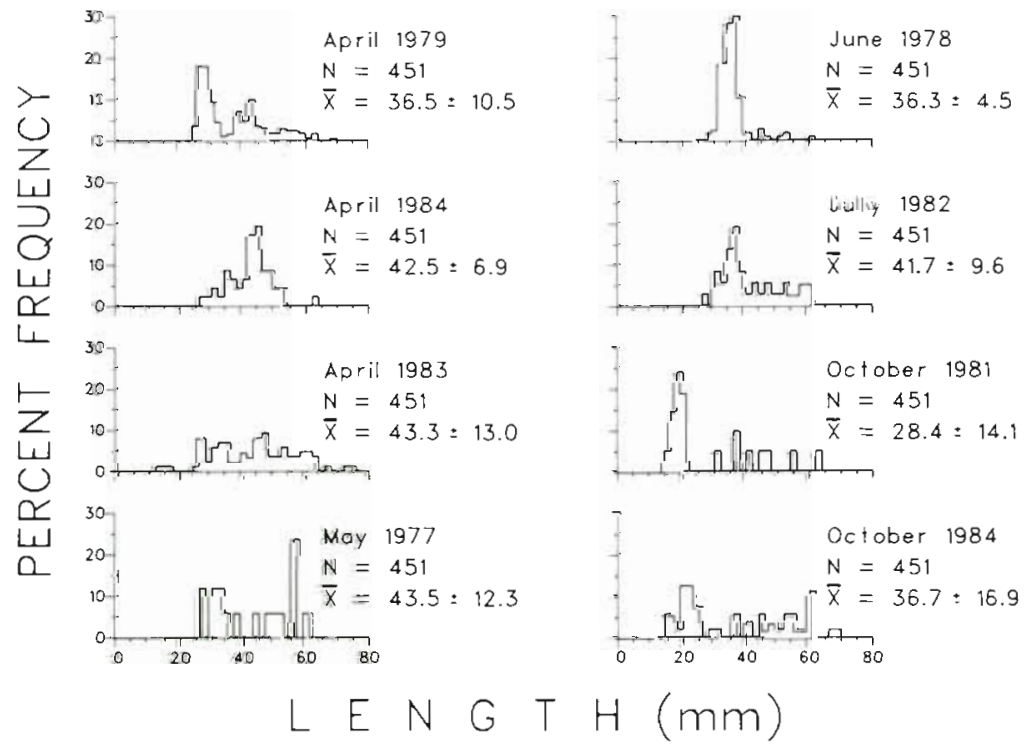



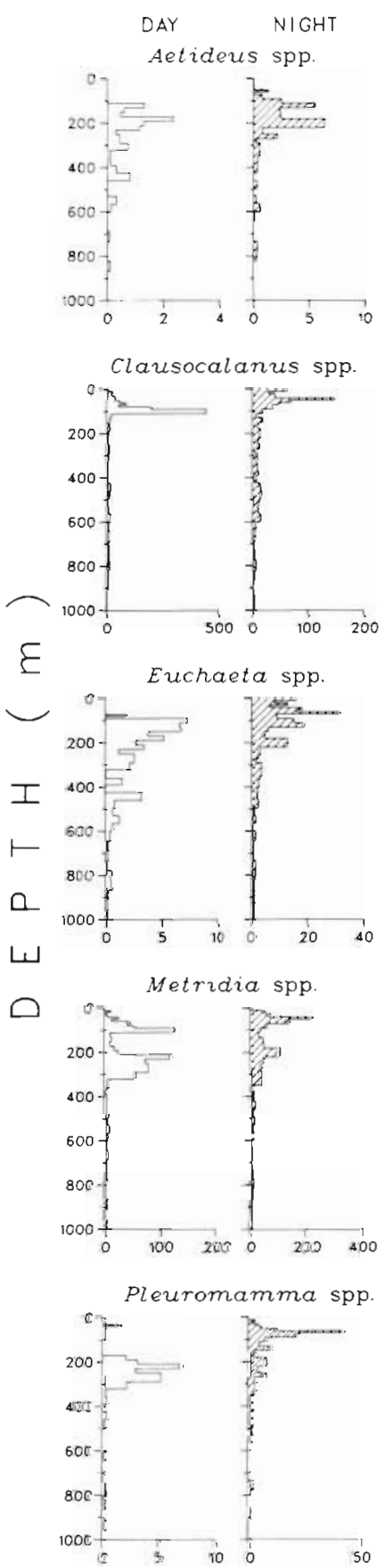

$N \cup M$
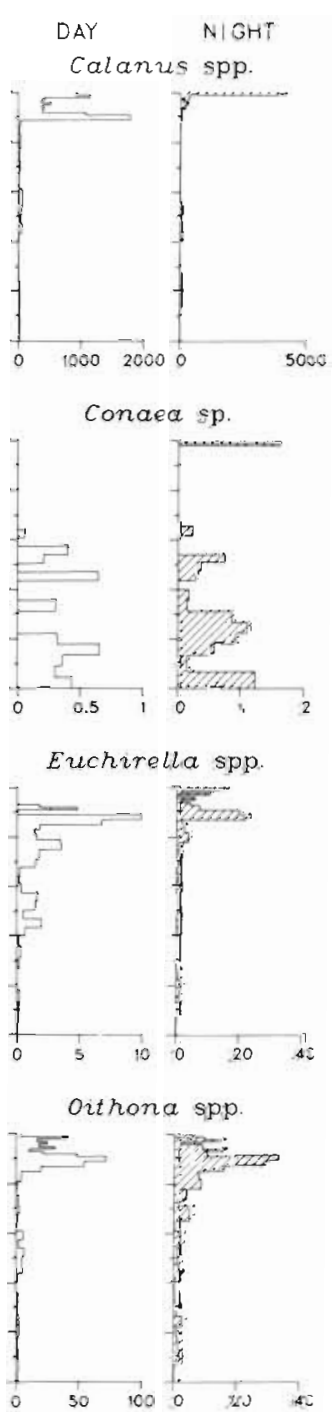

Pseudocalanus minutus

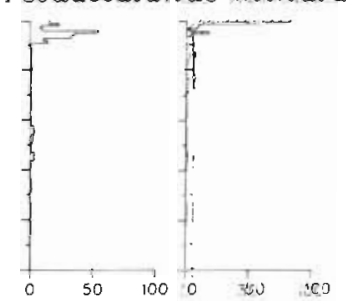

B E R

P E R

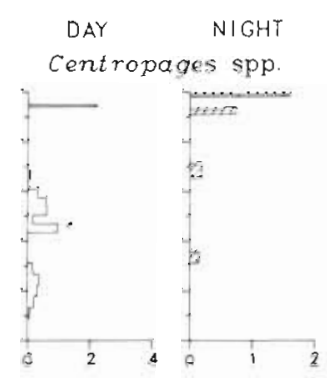

Eucalanus spp
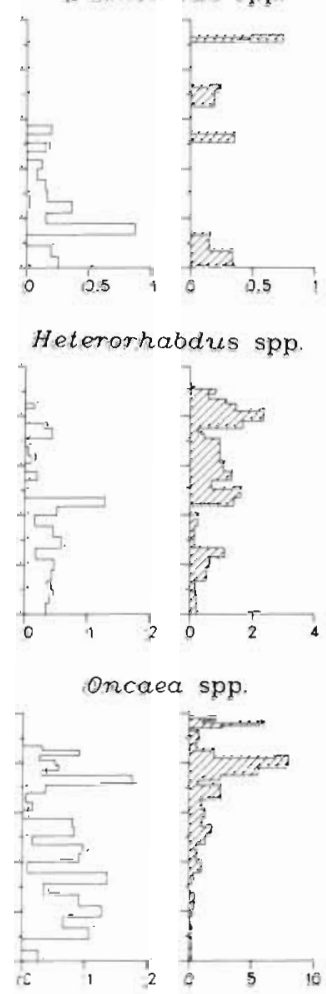

Scolecithricella spp.

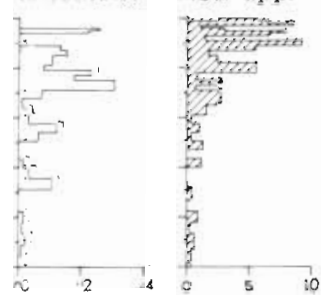

$M^{3}$

Fig. 4a. Concentrations of copepod genera, day and night, in April 1983, to $1000 \mathrm{~m}$ depth

night to the upper $200 \mathrm{~m}$, with the peak concentration generally found at about $30 \mathrm{~m}$ and only a few fish remaining at daytime depths (Fig. 6). In October the myctophid population did not demonstrate the same strong vertical migration at night and a large proportion of the fish remained at daytime depths during the night.

\section{Feeding of Benthosema glaciale}

By comparing the percentages of different groups and genera of invertebrates in the top $600 \mathrm{~m}$ of the water column at night with those found in the stomachs of Benthosema glaciale it was established that, with a few exceptions, this fish was an opportunistic feeder 

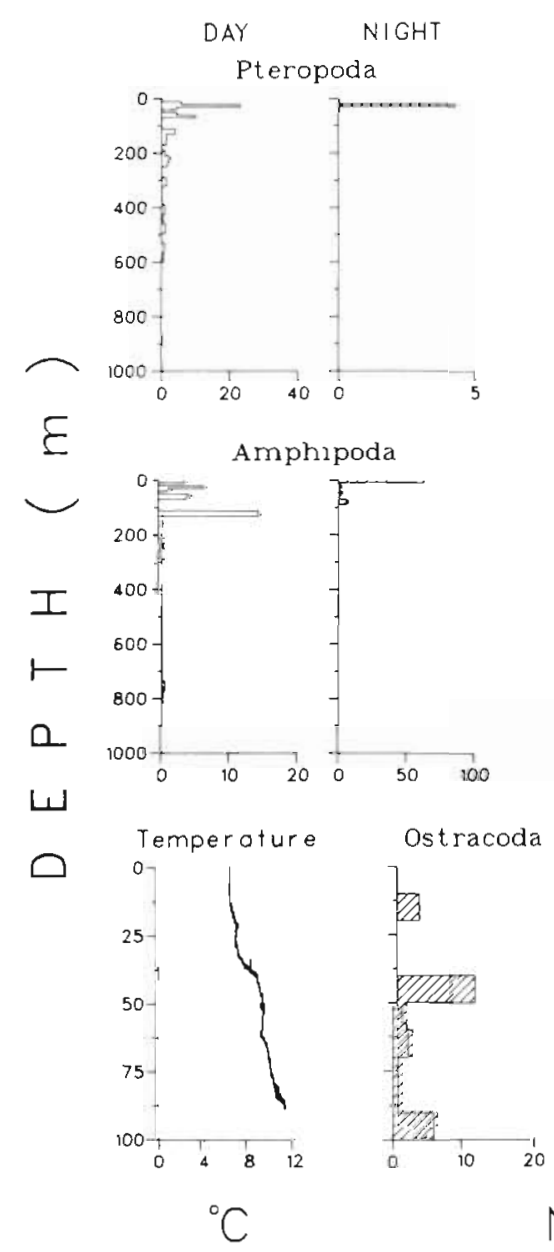

\section{N}

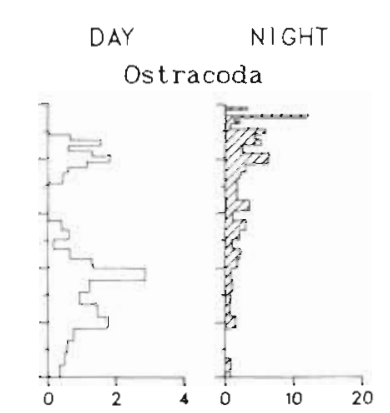

Euphausıacea

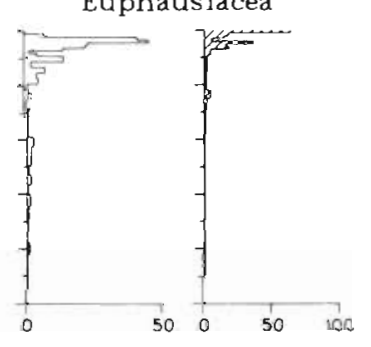

Copepoda
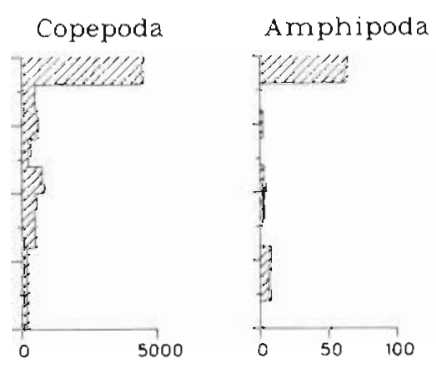

$\cup M B$

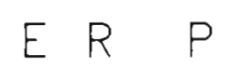

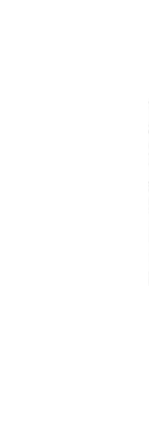
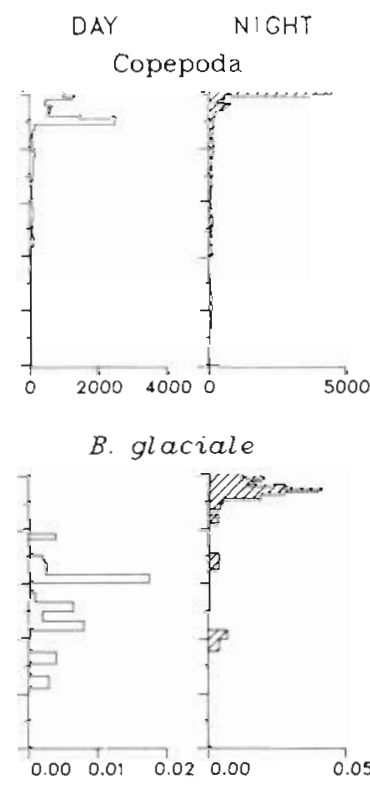

Fig. 4b. Concentrations of zooplankton groups, day and night, in April 1983 to 1000 m depth, plus (lower row) temperature profile and distribution of the main zooplankton groups and Benthosema glaciale in the top $100 \mathrm{~m}$ at night

taking various organisms in direct relation to their abundance (Table 4). In June there was some indication that copepods were selected over other prey such as euphausiids and amphipods (Table 4). In April the smaller copepod genera such as Clausocalanus, Oithona, Paracalanus, Oncaea and Gaidius appeared to be selected less frequently than their abundance in the samples, while in June Calanus was selected less frequently than during April.

\section{April}

Feeding occurred primarily between 20:00 and 03:00 h when the population was in the upper $200 \mathrm{~m}$ of water. The evidence for this was the large numbers of fish at different depths with $100 \%$ stomach fullness (Table 5). The population during daylight hours had low numbers of fish with $100 \%$ stomach fullness and high numbers with empty stomachs, whereas the fish caught at night had a high percentage of $100 \%$ fullness and a low percentage of empty stomachs. Maximum stomach fullness in the population occurred between 01:00 and 03:00 $\mathrm{h}$ as did the highest percentage of undigested prey (Table 6) indicating that more active feeding occurred at this time. However data on both fullness and degree of digestion indicated that some daytime feeding occurred. The percentages of different prey in the stomachs of fish caught during the day at 14:00 h and at night (Table 7 ) also suggested that some feeding occurred during the day at depths below $350 \mathrm{~m}$.

The stomachs of fish caught in April during the day at a mean depth of $430 \mathrm{~m}$ contained material that was usually well digested and unrecognizable. These fish also contained remains of prey such as ostracods and chaetognaths that were not found in the stomachs of the fish at night (Table 7 ), indicating daytime feeding. The percentage of amphipods and euphausiids in the stomachs was much higher during the day than at any depth during the night which indicated that day feed- 

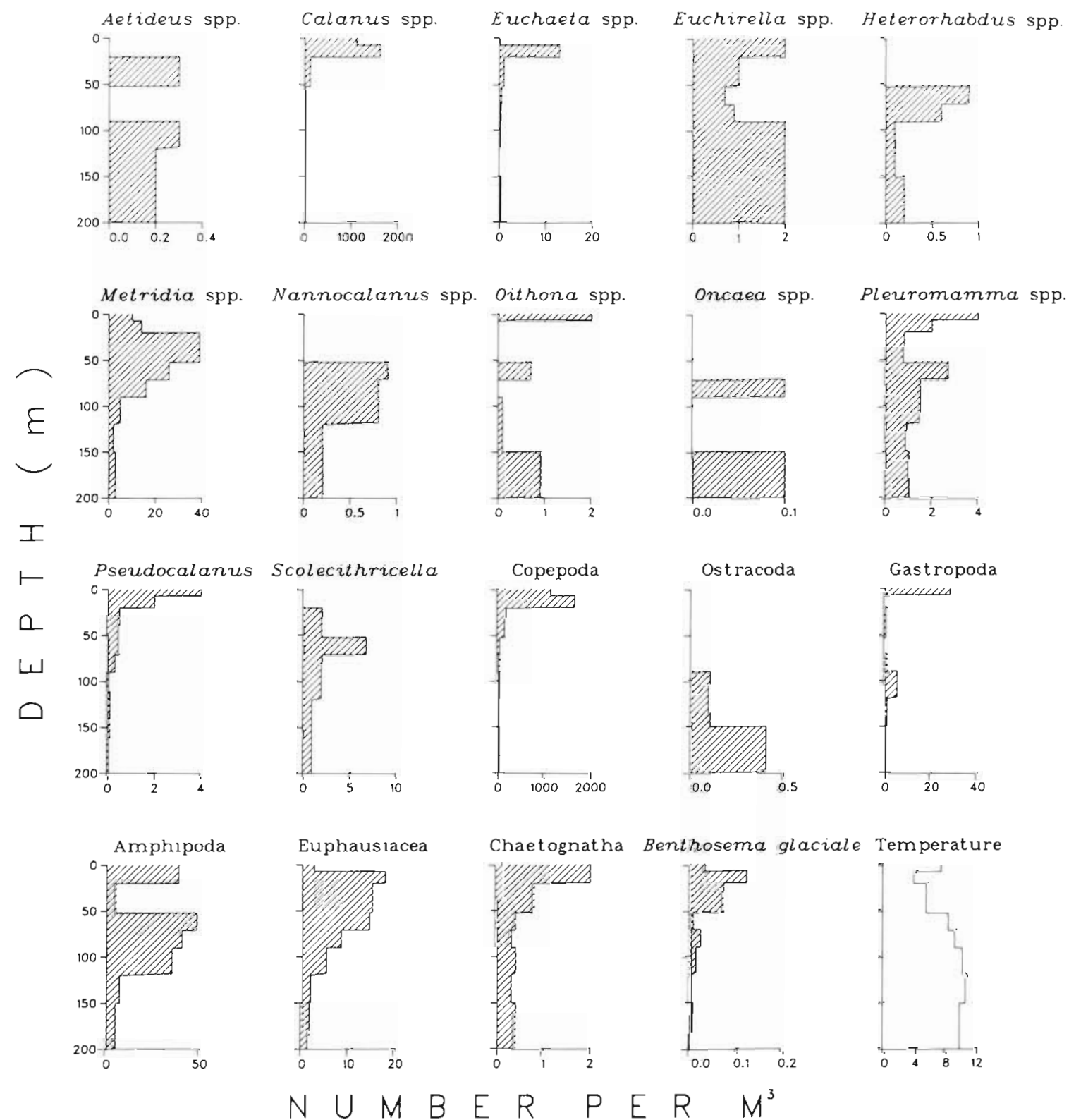

Fig. 5. Concentrations of zooplankton groups, copepod genera, Benthosema glaciale and the temperature profile to $200 \mathrm{~m}$ at night during June 1978

ing on these groups occurred even though they were found at very low concentrations at the myctophid daytime depths (Fig. 4). The modified Ivlev's $D_{1,}$ calculated for all the groups and genera for the daytime depth stratum, and 6 different depth strata at night (Table 7), showed that during the day the fish positively selected amphipods, euphausiids and chaetognaths but no other groups. During the night pteropods were positively selected at depths below $60 \mathrm{~m}$, and euphausiids were selected at 4 of the 6 depth strata. Copepods were not positively selected at any depth stratum except $307 \mathrm{~m}$. Some groups appeared to be selected against by Benthosema glaciale; gastropods, ostracods, gynnosomata, amphipods, and chaetognaths all had negative $D_{i}$ values at night.

The various genera of copepods found in the stomachs were arranged in order of increasing body length (Table 7) which demonstrated that the fish showed a preference for copepod genera greater than $1.0 \mathrm{~mm}$ in length. The most prefered genera were 
Fig. 6. Benthosema glaciale. Day/ night vertical distribution during different months

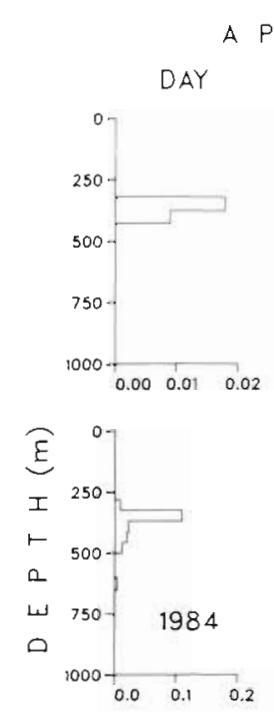

$P R 1 L$

NIGHT
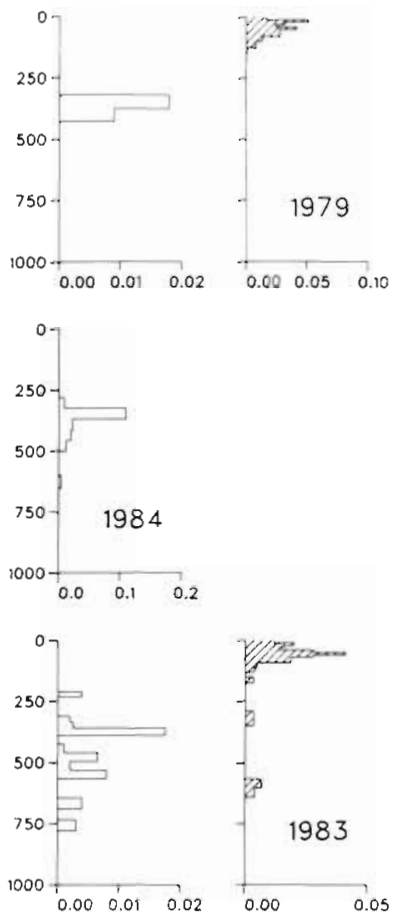

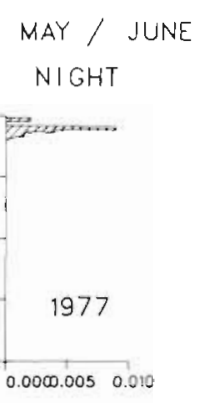

O C T O B E R

DAY

NIGHT

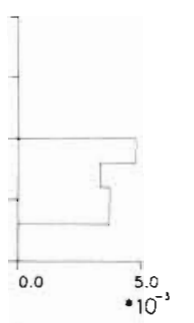

Zat

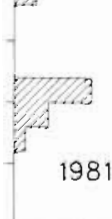

0.0000 .0050 .010
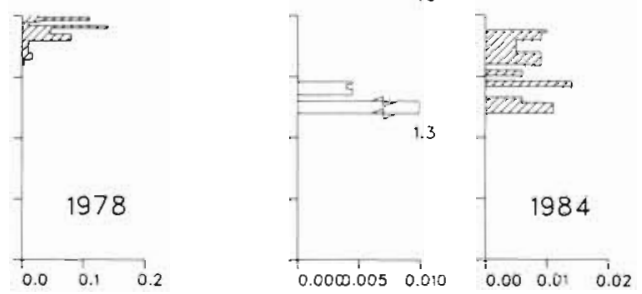

$N \cup M B E R \quad P E R \quad M^{3}$

Aetideus and Pleuromamma as indicated by the high mean night value of $D_{1}$. A higher preference for these geñera was usuáliy shown in the deeper strata. Ihe most common organism in the stomachs at all depths was Calanus, principally C. finmarchicus C4. However, it was selected less than its percentage in the plankton samples in all strata but the deepest; this may have been an artifact resulting from fish feeding in the upper strata and returning with their prey to deeper water.

Euphausiids and pteropods (Limacina spp.) were the only groups that were positively selected for at night. Pteropods were only found in fish caught in deep water at night, and these fish had few other organisms in their stomachs. Possibly pteropods were captured in the upper strata during a previous feeding and the undigested shell was all that remained or was captured during the day between 300 and $500 \mathrm{~m}$.

June

In June the populations of both Benthosema glaciale and zooplankton reached their highest levels of all the months sampled (Table 1). Stomach contents of myctophids in the upper $150 \mathrm{~m}$ during the night were similar to those in April (Table 8). However, small copepods, such as Microcalanus and Paracalanus, were found in the stomachs at low concentrations and the remains of fish larvae were common. Calanus, Metridia and Pleuromamma were the most common genera eaten, as in April. A positive $D_{i}$ for Pleuromamma, Euchireilla and Euchaeta was shown at most depth strata. Copepods as a group dominated the diet of the fish during June with the percentage of stomach contents made up of copepods slightly decreasing with depth (Table 8). The fish showed a preference for prey with a body length greater than $1 \mathrm{~mm}$, as in April.

\section{October}

Twenty Benthosema glaciale ranging in size from 15 to $54 \mathrm{~mm}$ were analyzed for stomach contents and only 7 contained prey. All 7 contained only copepods, and only 2 of these had recognizable prey items, Oncaea in one stomach and Metridia and Pleuromamma in both. The other 5 stomachs contained digested and unrecognizable copepods. One fish with a $100 \%$ full stomach was caught at night at a depth of $35 \mathrm{~m}$, the other 6 were only $1 \%$ full and were caught equally during night and day at depths between 40 and $700 \mathrm{~m}$. The high percentage of empty stomachs may have resulted from the fish not feeding at this time of year or to the scarcity of prey which was much lower than at the other times of the 
Table 4. Percentage of water samples and Benthosema glaciale stomachs that contained various prey groups and genera for April 1979 in the top $600 \mathrm{~m}$ and June 1978 in the top $150 \mathrm{~m}$

\begin{tabular}{|lcccc|}
\hline Group/genus & \multicolumn{3}{c}{ April } & \multicolumn{2}{c|}{ June } \\
& $\begin{array}{c}\text { Sample } \\
\%\end{array}$ & $\begin{array}{c}\text { Stomach } \\
\%\end{array}$ & $\begin{array}{c}\text { Sample } \\
\%\end{array}$ & $\begin{array}{c}\text { Stomach } \\
\%\end{array}$ \\
\hline Group & & & & \\
Copepods & 76 & 79 & 74.3 & 91.3 \\
Euphausids & 2 & 3 & 5.6 & 1.4 \\
Ostracods & 1 & 0.08 & 0.0 & 0.0 \\
Amphipods & 0.5 & 0.01 & 14.5 & 2.0 \\
Chaetognaths & 0.2 & 0 & 0.3 & 0.0 \\
Gynnosomata & 0.2 & 0 & 0.0 & 0.1 \\
Genus & & & & \\
Calanus & 24 & 24 & 66.9 & 46.0 \\
Metridia & 19 & 9 & 21.6 & 14.9 \\
Clausocalanus & 9 & 1 & & \\
Pleuromamma & 4 & 5 & 1.0 & 1.4 \\
Oithona & 4 & 0.07 & 0.2 & 0.1 \\
Euchaeta & 3 & 3 & 1.1 & 2.6 \\
Euchirella & 2 & 3 & 1.2 & 0.5 \\
Paracalanus & 1 & 0.04 & 0.0 & 0.6 \\
Scolecithricella & 1 & 0.05 & 2.8 & 0.1 \\
Oncaea & 0.6 & 0.1 & & \\
Aetidius & 0.5 & 2 & 0.2 & 0.0 \\
Pseudocalanus & 0.4 & 0.4 & 4.3 & 1.6 \\
Neocalanus & 0.2 & 0.1 & & \\
Gaidius & 0.2 & 0.02 & & \\
Heterorhabdus & 0.1 & 0 & & \\
Centropages & 0.06 & 0 & & \\
Mormonilla & 0.01 & 0.02 & & \\
\hline
\end{tabular}

Table 5. Benthosema glaciale. Percentages of stomach fullness for fish taken at night and day

\begin{tabular}{ccc|}
\hline Fullness (\%) & Day \% & Night \% \\
\hline 0 & 20 & 7 \\
1 & 13 & 12 \\
25 & 16 & 16 \\
50 & 27 & 23 \\
75 & 21 & 20 \\
100 & 3 & 22 \\
\hline
\end{tabular}

Table 6. Benthosema glaciale. Percentages of various digestion classes for all night and day data from all months

\begin{tabular}{|ccc|}
\hline Digestion class & Day \% & Night \% \\
\hline 1 & 57 & 24 \\
2 & 34 & 48 \\
3 & 9 & 14 \\
\hline
\end{tabular}

year (Table 1). The mean concentrations of copepods per $\mathrm{m}^{3}$ at various depths where $B$. glaciale were found were extremely low ranging from a high of 99 copepods $\mathrm{m}^{-3}$ at $300 \mathrm{~m}$ to a low of $3 \mathrm{~m}^{-3}$ at $50 \mathrm{~m}$ depth. The dominant copepod in the upper $100 \mathrm{~m}$ was Clauso calanus arcuicornis and at 300 to $400 \mathrm{~m}$ it was Pleuromamma glacilis.

\section{Relation between fish body length and prey length}

Benthosema glaciale collected from all months and years were grouped into length classes and compared with the length of each prey item found in their guts (Fig. 7). The smallest particles in the guts were approximately $0.5 \mathrm{~mm}$ in length and the largest $7 \mathrm{~mm}$. The upper size range of the prey particles increased as the length of fish increased, but the size of the smallest particles did not change except for those in the largest ( 70 to $79 \mathrm{~mm}$ ) size class. There was no significant statistical difference in the length range of prey particles in fish of lengths between 20 to $79 \mathrm{~mm}$. Fish between 10 and $19 \mathrm{~mm}$ contained significantly smaller prey than fish greater than $19 \mathrm{~mm}$. The volumes of the prey particles were calculated, assuming the particles to be spheres and plotted in a similar manner to the particle lengths, with similar results.

\section{Relation between fish body weight and weight of stomach contents}

The ratio between the wet body weight and wet weight of stomach contents of fish judged to be $100 \%$ full decreased with increasing body weight (Fig. 8). The smallest fish had the highest percentage of weight of stomach contents to body weight (up to $9.6 \%$ for a fish $16 \mathrm{~mm}$ in length). A regression equation between the body weight (in $g$ ) and fish ration $(R)$ was calculated where $R$ was equal to (wt of stomach contents)/(body wt) $\times 100$. The regression equalled:

$$
\mathrm{R}=4.46 \text { body } \mathrm{wt}^{-0253}
$$

which was highly significant $(t=9.5$ for the intercept and -3.6 for the slope, $\mathrm{df}=82 ; p=0.001$ ).

The relation between total length and wet weight of Benthosema glaciale (Fig. 9) was used to estimate the mean body weight for each of the sample months (Table 1). These values were used to estimate the percentage of the body weight consumed in prey by the average fish for each month using Eq. (1). This value was used to estimate the total biomass of zooplankton consumed per day by the total population of myctophids per $\mathrm{m}^{2}$, for the different months (Table 1 ). The assumption was made that the maximum daily ration per fish is equal to the amount of prey found in a $100 \%$ full stomach. This assumption would underestimate the true daily ration if the fish passed food from 


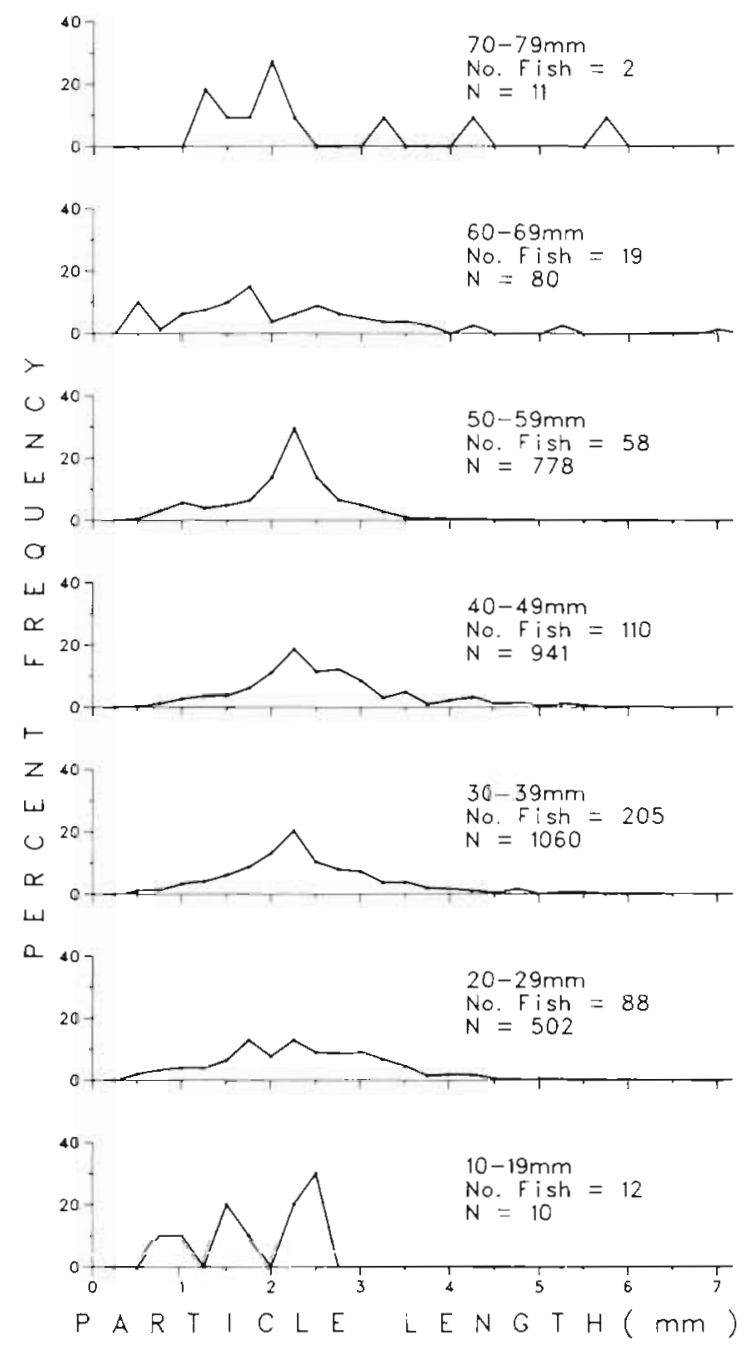

Fig. 7 Prey particle length vs particle frequency in the guts of various size classes of Benthosema glaciale taken from samples of different months

the stomach to the gut as it fed and maintained a full stomach. Therefore the values estimated for daily rations are probably underestimated.

\section{DISCUSSION}

The total biomass of myctophids per $\mathrm{m}^{2}$ off the shelf break in April and June was approximately an order of magnitude higher than the value reported by Gjøsaeter \& Kawaguchi (1980) who, using data from Jahn \& Backus (1976), estimated the biomass of mesopelagic fish in the top $200 \mathrm{~m}$ at night in the slope water off the Scotian shelf to be $0.2 \mathrm{~g} \mathrm{~m}^{-2}$. Chapman et al. (1974), using acoustics, showed the biomass to be $0.5 \mathrm{~g} \mathrm{~m}^{-2}$ on the Scotian Shelf. Generally, acoustic estimates of

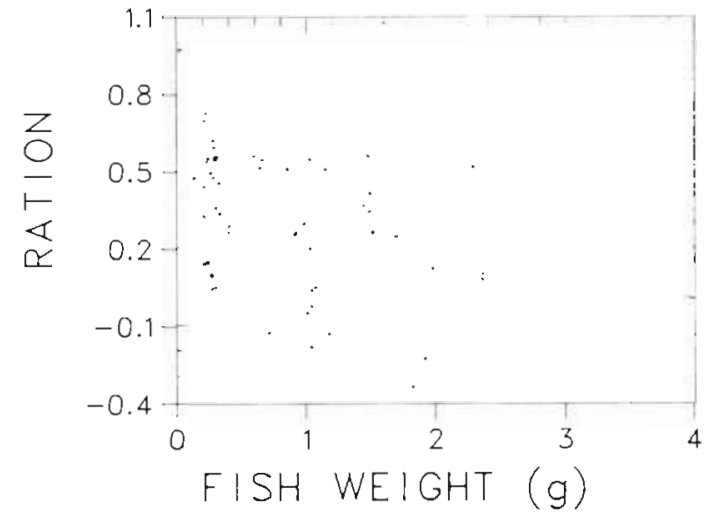

Fig. 8. Benthosema glaciale. Relation between $\log _{10}$ weight of prey in $\%$ full stomachs (ration) to wet weight of fish

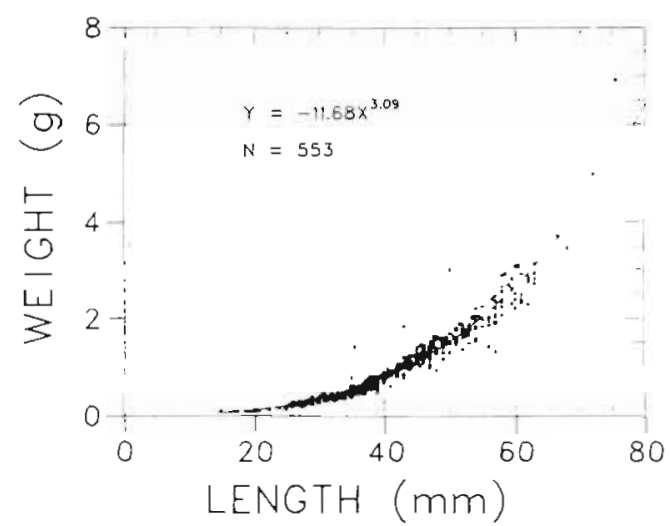

Fig. 9. Benthosema glaciale. Relation between wet body weight and total length. Fish were taken from all sampled months

mesopelagic fish are higher than biomass estimates made with nets (Gjøsaeter \& Kawaguchi 1980) and observations made from submersibles are much higher than either net or acoustic estimates (Milliman \& Manheim 1968, Alldredge et al. 1984). Therefore it is possible that the BIONESS underestimated the biomass and concentration of Benthosema glaciale in this study and therefore the impact of this species on the zooplankton community of the slope, even though the biomass estimates are much higher than those of previous studies. However, the data for different months were collected during different years, so interpreting these data as showing seasonal changes should be done with caution because of the large interannual variation in the data.

The very low concentration of Benthosema glaciale found in October coincided with a warm water mass in the upper $600 \mathrm{~m}$. The reduction in the B. glaciale population may have been due either to fish migrating to a region of colder water or else to their being advected away from the sampled area during the sum- 


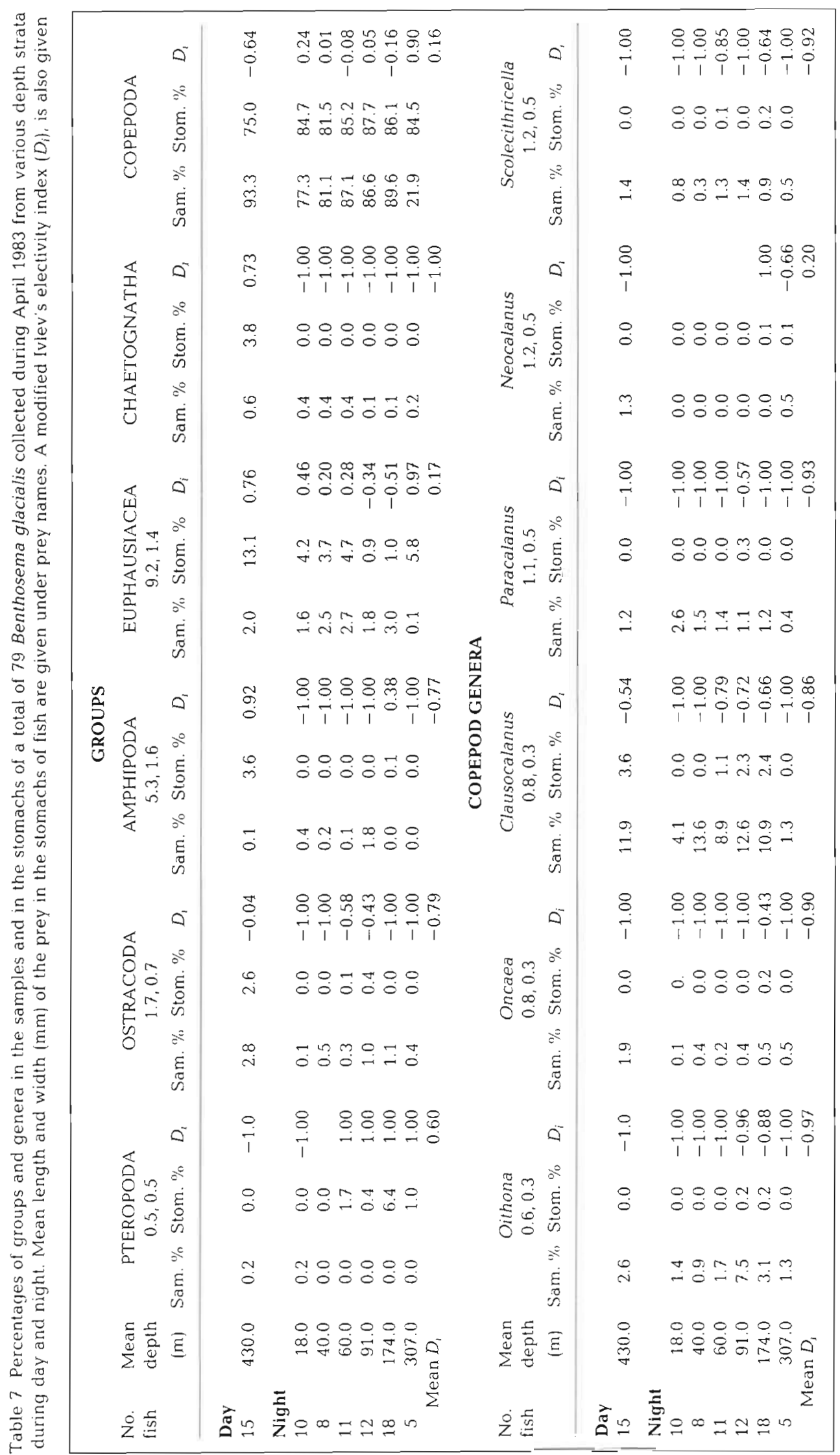




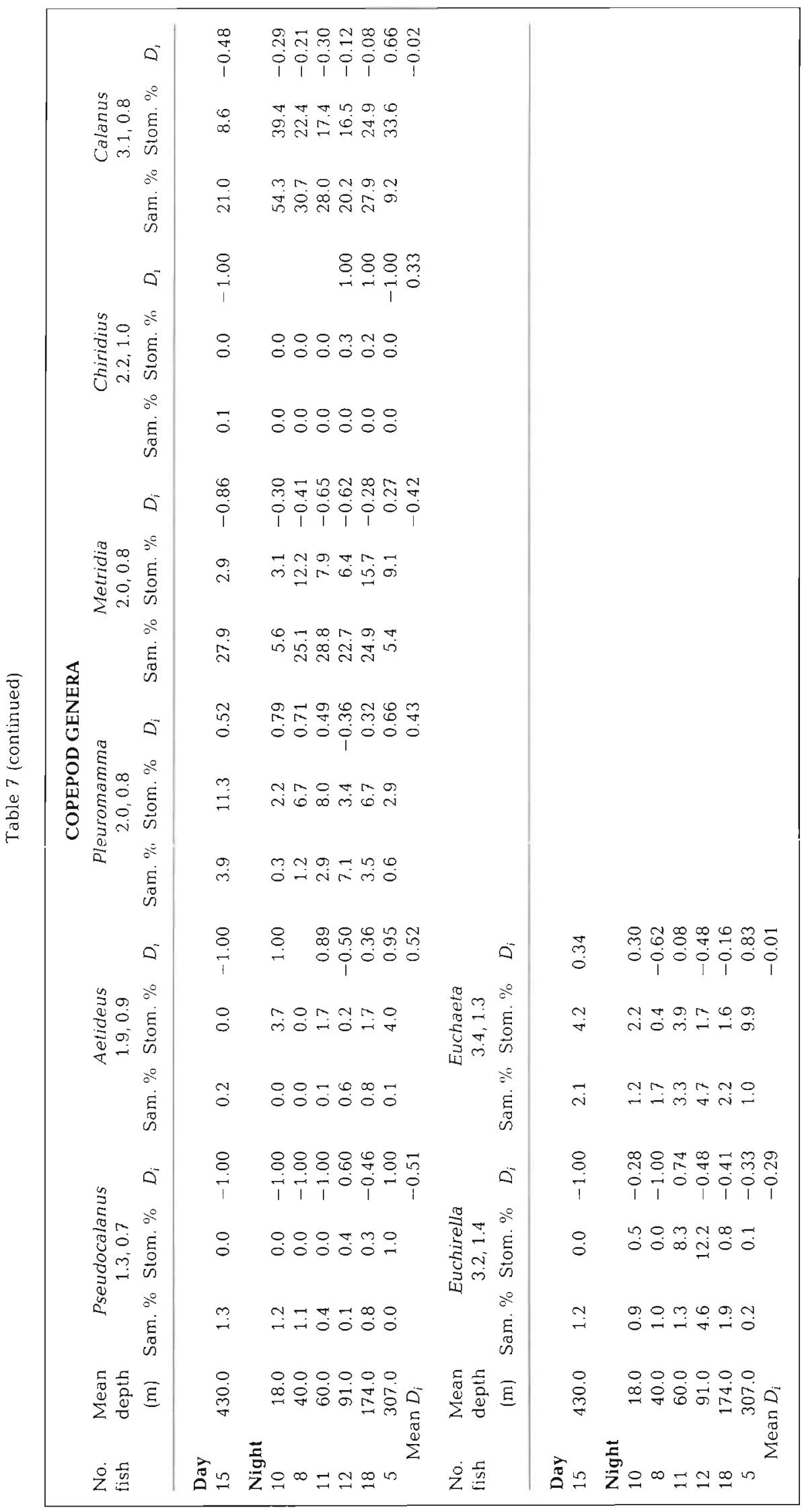




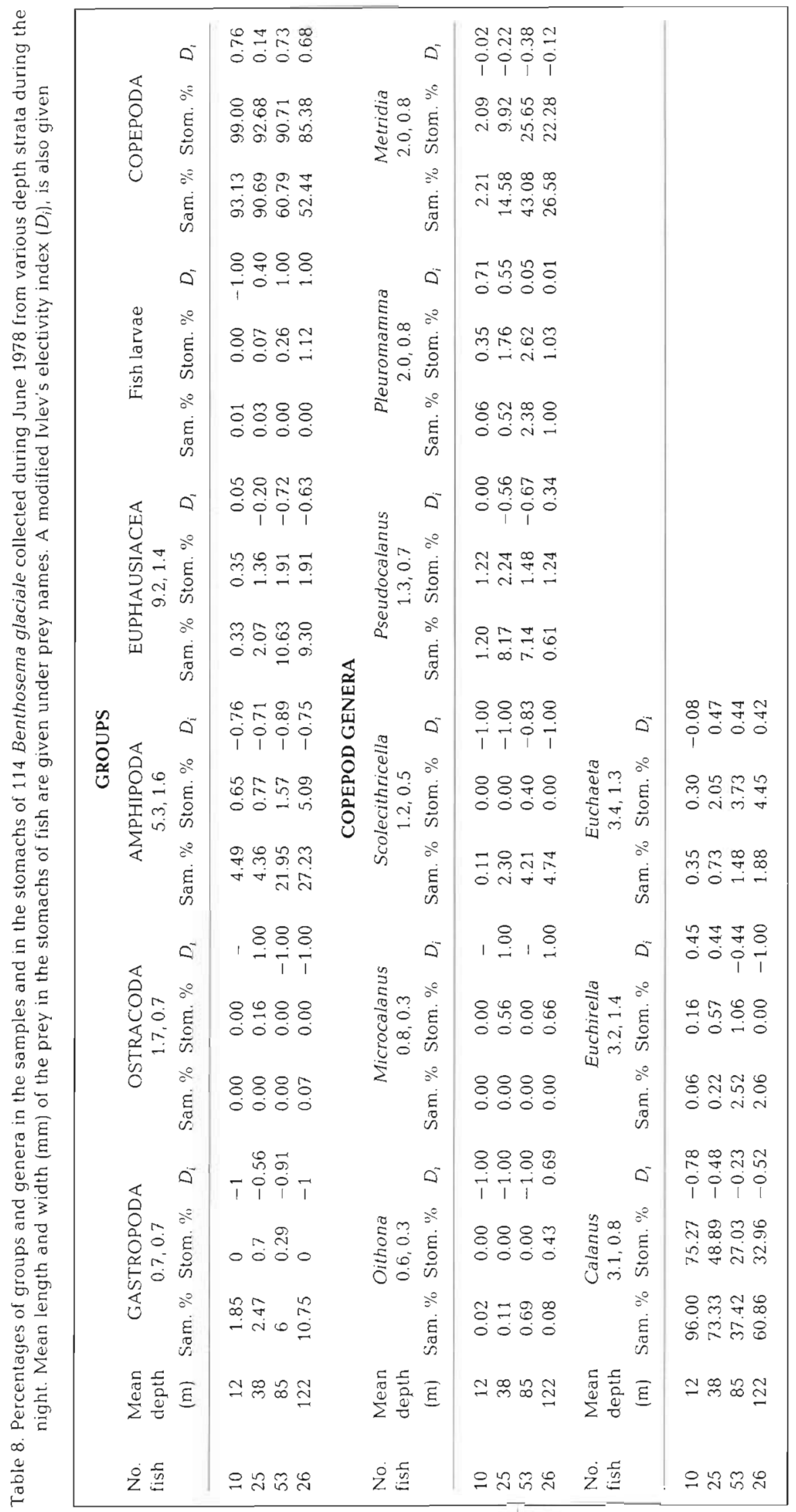


mer as the water was displaced by warmer water. Samples taken from depths down to $1400 \mathrm{~m}$ in October showed that the fish did not migrate deeper than their normal daytime depth of 300 to $800 \mathrm{~m}$ to avoid the warm water. The most likely explanation is that the fish remained with the cold water mass as it moved to the southwest, though few data exist on water mass movement in this region. The B. glaciale population probably reappears in the late winter or early spring with the re-appearance of the cold water of the Labrador Current from the northeast.

The daytime vertical distribution of Benthosema glaciale showed a population concentration between 300 and $550 \mathrm{~m}$ with a maximum between 320 and $360 \mathrm{~m}$. These results were similar to those of Halliday (1970) who found the daytime centre of vertical distribution below $450 \mathrm{~m}$. In the present study a few fish were caught during the day in the upper $30 \mathrm{~m}$, and in all cases these fish had empty stomachs. It is reasonable to suggest that hunger may have caused these fish to break from the normal day/night vertical migration pattern. During the night the majority of the population was found below the main concentration of copepods which was in the upper $30 \mathrm{~m}$ even though the highest concentration of B. glacialis was commonly found with the highest concentration of copepods. This suggests that most fish either feed below the highest concentrations of prey or else make short excursions into the upper layers to feed and then return to the deeper water below the zooplankton maximum. The latter suggestion is supported brr the stomach contents of the fish in the top $200 \mathrm{~m}$ which contained a higher percentage of Calanus, a species concentrated in the top 30 to $50 \mathrm{~m}$ during all months.

Benthosema glaciale in other regions feed primarily at night, but also feed during the day (Kinzer 1977). In the present study the feeding pattern was similar to that reported by Kinzer (1977) in the Central Atlantic with the highest percentage of $100 \%$ full and lowest percentage of empty stomachs being found between 22:00 and 03:00 $\mathrm{h}$.

The daily ration of Benthosema glaciale, defined as the ratio between body weight and the weight of the contents of a $100 \%$ full stomach, was similar to that of Lampanyctus mexicanus in the Gulf of California which ranged between 3.7 and $6.1 \%$ (Holton 1969). Baird et al. (1975) found the maximum prey biomass for Diaphus taaningi from the Cariaco Trench was $0.8 \%$ of dry body weight. Tseytlin \& Gorelova (1978) estimated the specific daily ration of Myctophum nitidulum in the equatorial Pacific of length of 11 to $20 \mathrm{~mm}$ to be $13 \%$ of body weight. The smallest Benthosema glaciale on the Scotian slope (about $16 \mathrm{~mm}$ ) had a daily ration range of 3 to $10 \%$ of body weight. These fish live in water at 4 to $8.5^{\circ} \mathrm{C}$, while $M$. nitidulum lives at between 22 and
$34{ }^{\circ} \mathrm{C}$ suggesting a higher metabolic rate, and probably a higher ration.

Use of the weight of the contents of $100 \%$ full stomachs as a measure of the daily ration most likely underestimated the true ration, for some food was problably digested within $24 \mathrm{~h}$ or had passed from the stomach into the gut.

Roe \& Badcock (1984) reported that Benthosema glaciale positively selected Metridia lucens but avoided the more numerous Clausocalanus, suggesting that $B$. glaciale selects its prey according to size. They found that $B$. glaciale actively fed at night, but that it also fed at its daytime depth, in agreement with the results of this study. Gjøsaeter (1973b) observed that feeding of $B$. glaciale was greatest during the spring and summer, decreasing in fall and winter. He suggested that there may be a relationship between degree of filling of the stomachs and the volume of zooplankton per $\mathrm{m}^{3}$, which was highest during spring and summer, as also found in the present study which showed a low level of feeding in October when the zooplankton concentration was very low. Gjøsaeter (1973b) found no relationship between feeding and temperature at the daytime depth of $B$. glaciale. On the Scotian slope the temperature at this depth showed a significant increase from April to October indicating greater penetration of warmer slope water late in the year. This warmer slope water had very low concentrations of zooplankton and B. glaciale associated with it. Such low zooplankton concentrations may have influenced the feeding behavion of $D$. yiaciale so that few fish migrated vertically at night to feed in the upper water. Baird et al. (1975) estimated that the minimum prey density needed for feeding by Diaphus taaningi in the Cariaco Trench was $154 \mathrm{~m}^{-3}$. One can only speculate how long the population of $B$. glaciale on the Scotian slope could survive the zooplanktonimpoverished October water mass with prey concentrations of 50 to $99 \mathrm{~m}^{-3}$ at their daytime depth and 3 to $14 \mathrm{~m}^{-3}$ at their night-time depths.

Hartmann (1970) reported that 3 species of pleustonic fish in the subtropical North Atlantic broaden their food spectrum with increasing length, with the larger fish eating larger prey and abandoning the smaller prey. Paxton (1967) showed that in the California current system only the largest specimens of 2 species of myctophids fed on fish. Scotto di Carlo et al. (1982) stated that the smallest Hygophum benoiti in the Straits of Messina tended to feed exclusively on copepods while the larger specimens shifted toward an euphausiid diet. They found that Myctophum punctatum had a mixed diet at all stages of their growth with prey diversity increasing with fish size. The pattern of increased prey diversity with increased body size was also shown for Stenobrachius leucopsarus in the east- 
ern Pacific (Collard 1970, Tyler \& Pearcy 1975). Benthosema glaciale in the present study broadened its food spectrum with increasing fish length, but did not appear to stop feeding on the smallest prey as Hartmann (1970) reported for the pleustonic fish. This means that the largest specimens of $B$. glaciale had the widest prey size range. Kinzer (1982) reported that $B$. glaciale var. thori in the Central Atlantic below $30 \mathrm{~mm}$ length fed primarily on copepods, but that individuals $>30 \mathrm{~mm}$ also fed on euphausiids. Scotian slope specimens showed no indication of increased feeding on euphausiids with increased body length.

Scott di Carlo et al. (1982) reported that Hygophum benoiti and Myctophum punctatum rarely fed on small copepods (about $1 \mathrm{~mm}$ ) and suggested this was due to the species using visual cues to locate their prey - large bioluminescent copepods such as Pleuromamma spp. Scotian slope Benthosema glaciale showed the highest positive selection for Pleuromamma spp. out of all the copepods off the Scotian shelf, the most common species being $P$. borealis. Metridia and Calanus, both of which were as large or larger than Pleuromamma and much more numerous, were negatively selected. These 2 genera were not concentrated at the same night-time depths as the main population of myctophids, whereas Pleuromamma was concentrated at these depths during both the day and night. It is also quite likely that Pleuromamma and B. glaciale vertically migrated in syncrony since they had similar day/ night distributions, subjecting Pleuromamma to almost continuous predation.

Gjøsaeter (1973a) stated that Benthosema glacialis in Norwegian waters grows faster and has a higher maximum length than it does off Nova Scotia. The largest specimen reported outside Norwegian waters was one taken in Greenland measuring $84 \mathrm{~mm}$ (Jensen 1948) which was estimated to be 7 to $8 \mathrm{yr}$ old. The largest specimen collected by Halliday (1970) off the Scotian shelf was approximately $58 \mathrm{~mm}$, much smaller than those collected during the present study. The difference in the maximum sizes of the fish $183 \mathrm{~mm}$ for this study vs $58 \mathrm{~mm}$ for Halliday 1970) may have been due to the different types of the sampling gear used. Halliday used a $6 \mathrm{ft}(1.8 \mathrm{~m})$ Isaccs-Kidd midwater trawl which may be less efficient at capturing the larger $B$. glaciale. The presence of the large fish during May could have indicated a population of fish carried to the Scotian shelf region by the Labrador Current from the Labrador coastal region where a population of older and larger fish is reported to exist (Gjøsaeter 1973a).

Halliday (1970) found much lower numbers of Benthosema glaciale during September and October than in spring, sampling south of the area sampled in October in the present study. However B. glaciale was very abundant during September and October east of the
Grand Banks in the region of the Labrador Current. This suggests that the presence of $B$. glaciale along the edge of the Scotian shelf may be related to the presence of the colder Labrador Current water in spring and summer, which was not present in October.

Acknowledgements. I thank Ms M. K. Lewis for her very able assistance in the analysis of data and Drs R. J. Conover and A $R$. Longhurst for their critical and constructive reviews of the manuscript.

\section{LITERATURE CITED}

Alldredge, A. L., Robison, B. H., Fleminger, A., Torres, J. J., King, J. M., Hammer, W. M. (1984). Direct sampling and in situ observation of a persistent copepod aggregation in the mesopelagic zone of the Santa Barbara Basin. Mar. Biol. 80: 75-81

Baird, R. C., Thomas, B., Hopkins, L., Wilson, D. F. (1975). Diet and feeding chronology of Diaphus taaningi (Myctophidae) in the Cariaco Trench. Copeia 2: 356-365

Chapman, R. P., Bluy, O. Z., Adington, R. H., Robison, A. E. (1974). Deep scattering layer spectra in the Atlantic and Pacific oceans and adjacent seas. J. acoustic Soc. A.m. 56: $1722-1734$

Clarke, T A. (1978). Diel feeding patterns of 16 species of mesopelagic fishes from Hawaiian waters. Fish. Bull. U.S. 76: $495-513$

Clarke, T A. (1980). Diets of fourteen species of vertically migrating mesopelagic fishes in Hawaiian waters. Fish. Bull. U.S. 78: 619-640

Collard, S. B. (1970). Forage of some eastern Pacific midwater fishes. Copeia 2: 348-354

Fedulov, T P., Arkhipkin, A. J. (1986). Distribution of mass species of pelagic squid in spring between Nova Scotia and the Sargasso Sea as a function of hydrologic and dynamic water structure. Oceanology 26: 229-234

Gjøsaeter, J. (1973a). Age, growth, and mortality of the myctophid fish Benthosema glaciale (Reinhardt), from western Norway. Sarsia 52: 1-14

Gjosaeter, J. (1973b). The food of the myctophid fish Benthosema glaciale (Reinhardt) from western Norway. Sarsia 52: $53-58$

Gjøsaeter, J., Kawaguchi, K. (1980). A review of the world resources of mesopelagic fish. FAO Fish. Tech. Pap. No. 193. FAO, Rome

Halliday, R. G. (1970). Growth and vertical distribution of the glacier lanterfish. Benthosema glaciale, in the Northwestem Atlantic. J. Fish. Res. Bd Can. 27: 105-116

Hartmann, J. (1970). Verteilung und Nahrung des Ichthyoneuston im subtropischen Nordostatlantik. 'Meteor' Forsch-Ergebn., Reihe D 8: 1-60

Holton, A. A. (1969). Feeding behavior of a vertically migrating lanternfish. Pacif. Sci. 23: 325-331

Hopkins, T L., Baird, R. C. (1975). Net feeding in mesopelagic fishes. Fish. Bull. U.S. 73: 908-914

Imsand, S. (1981). Comparison of the food of Triphoturus mexicanus and $T$ nigrescens, two lanternfishes of the Pacific Ocean. Mar. Biol. 63: 87-100

Ivlev, V. S. (1961). Experimental ecology of the feeding of fishes. Yale Univ. Press, New Haven, Conn.

Jacobs, J. (1974). Quantitative measurement of food selection. Oceologia (Berl.) 14: 413-417 
Jahn, A. E., Backus, R. H. (1976). On the mesopelagic fish fauna of slope water, Gulf Stream, and northern Sargasso Sea. Deep Sea Res. 23: 223-224

Kinzer, J. (1977). Observations on feeding habits of the mesopelagic fish Benthosema glaciale (Myctophidae) off NW Africa. In: Anderson, W. R., Zahuranec, B. J. (eds.) Oceanic sound scattering prediction. Plenum Press, New York, p. 381-392

Kinzer, J. (1982). The food of four myctophid fish species off Northwest A.frica. Rapp. P.-v. Réun Cons. int. Explor. Mer 180: 385-390

Lancraft, T. M., Robison, B. H. (1980). Evidence of postcapture ingestion by midwater fishes in trawl nets. Fish. Bull. U.S. 77: 713-715

Milliman, J. D., Manheim, F. T. (1968). Observations in deepscattering layers off Cape Hatteras, USA. Deep Sea Res. 15: $505-507$

Paxton, J. R. (1967). A distributional analysis for the lanternfishes (Family Myctophidae) of the San Pedro Basin, California. Copeia 2: $422-440$

Roe, H. S. J., Badcock, J. (1984). The diel migrations and distribution within a mesopelagic community on the North
East Atlantic. 5. Vertical migrations and feeding of fish Prog. Oceanog. 13: 389-424

Rowedder, U. (1980). Feeding ecology of the myctophid Electrona antarctica, (Gunther, 1878) (Teleostei). Meeresforschung 27: 252-263

Sameoto, D. D. (1982). Zooplankton and micronekton abundance in acoustic layers on the Nova Scotian slope. Can. J. Fish. Aquat. Sci. 39: 760-777

Sameoto, D. D., Jaroszynki, L. O., Fraser, W. B. (1980). BIONESS, a new design in multiple net zooplankton samplers. Can. J. Fish. aquat. Sci. 37: 722-724

Scotto di Carlo, B., Costanzo, G., Fresi, E., Guglielmo, L., Ianora, A. (1982). Feeding ecology and stranding mechanisms in two lanternfishes, Hygophum benoiti and MYCtophum punctatum. Mar Ecol. Prog. Ser. 9: 13-24

Tseytlin, V. B., Gorelova, T. A. (1978). Study of the feeding of the lanternfish Myctophum nitidulum (Myctophidae, Pisces). Oceanology 18: 488-492

Tyler, H. R., Pearcy, W. G. (1975). The feeding habits of three species of lanternfish (Family Myctophidae) off Oregon, USA. Mar. Biol. 32: 7-11 